\title{
Parki Paryża w przestrzeniach odzyskanych
}

\section{Elżbieta Muszyńska, Krzysztof Muszyński}

\section{Wstęp}

Czym są tytułowe przestrzenie odzyskane?

To fragmenty miast, które w ostatnich dekadach XX w. utraciły swą dawną funkcję, lub z różnych względów przestały spełniać wymagania tej funkcji przypisane. Uległy degradacji funkcjonalnej i przestrzennej, stając się bolesnymi ranami w tkance miasta, przestrzeniami pozbawionymi życia. Wymagają więc zagojenia i rewitalizacji. Problem ten dotyczy przede wszystkim obszarów poprzemysłowych, ale także powojskowych i pokolejowych.

W większości wielkich miast, w których w XIX i na początku XX w. gwałtownie rozwijał się przemysł, pojawiła się konieczność nowego zagospodarowania terenów opuszczanych przez dotychczasowych użytkowników.

Najczęstszą i najlepiej sprawdzającą się nową funkcją takich terenów jest rekreacja. $\mathrm{Na}$ świecie istnieje wiele przykładów przekształcenia w parki publiczne terenów poprzemysłowych, powojskowych i pokolejowych. Ich tworzenie to często seria spektakularnych wydarzeń - od konkursu na projekt zagospodarowania, dyskusji publicznych podczas jego dopracowywania, aż po wykonanie założenia, a następnie jego promocja. Dodatkowym walorem założeń parkowych i rekreacyjnych, tworzonych w miejscach poprzemysłowych, powojskowych i pokolejowych jest możliwość wykorzystania i wyeksponowania zabytkowych elementów pozostałych po poprzednich użytkownikach. Taki park może stać się wyrafinowanym obiektem kultury i dziełem sztuki. Zapewnia wyższy standard życia i ma ogromne znaczenie dla budowania tożsamości i wizerunku miasta.

Najlepszym przykładem trafnego wykorzystania opuszczonych przez poprzednich użytkowników, czyli odzyskanych przez miasto obszarów jest Paryż. W tym wspaniałym mieście znajdziemy kilkanaście parków, które stworzono w końcu XX i na początku XXI w. na dawnych terenach pofabrycznych, składowych i kolejowych. Ich rozmieszczenie na planie Paryża przedstawia rycina 1. Każdy z nich ma swą specyfikę, jest oryginalny i niepowtarzalny. Francja to mekka projektantów zieleni miejskiej i architektów krajobrazu. Mieli oni w Paryżu wspaniałe pole do popisu i świetnie to wykorzystali. 


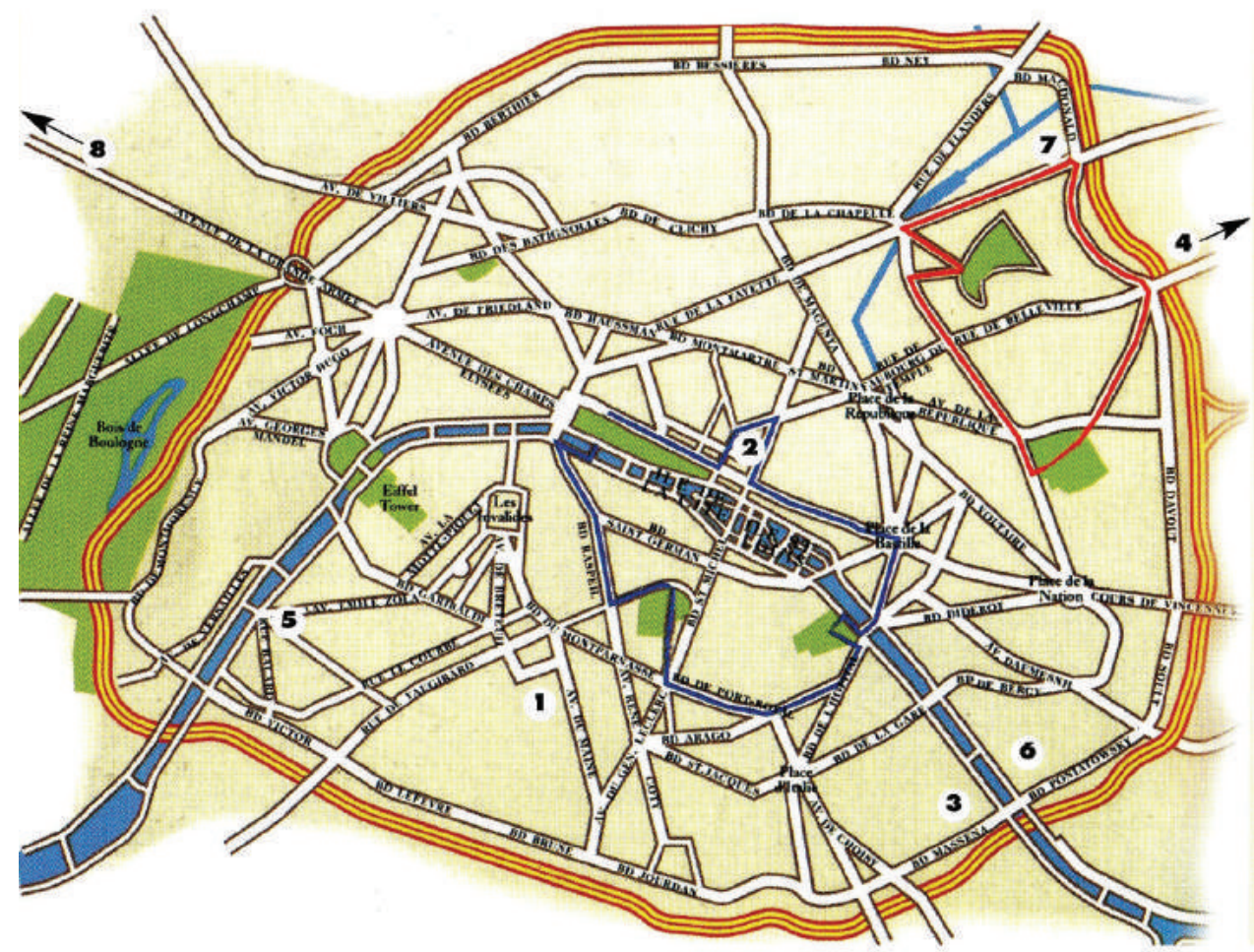

Ryc. 1. Schemat planu Paryża z lokalizacją parków Źródło: archiwum autorów

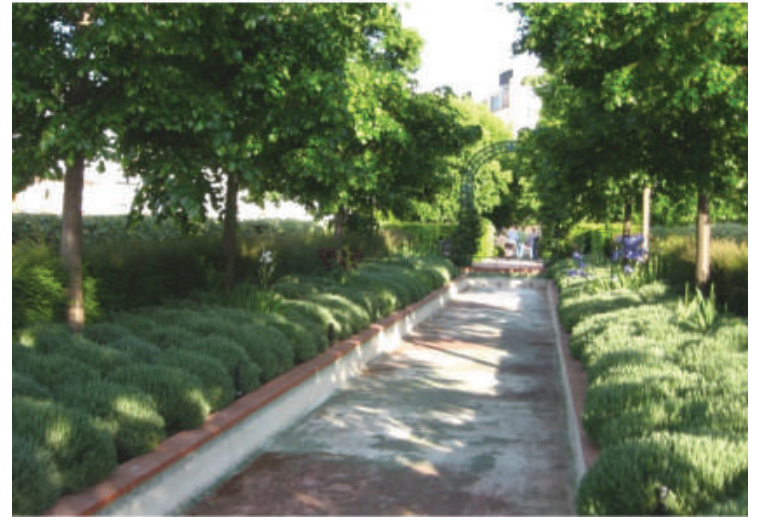

Fot. 1. Park Promenade Planteé w Paryżu Źródło: archiwum autorów

\section{Park Promenade Planteé}

Park ten, stworzony w latach 1988-1996 według projektu Philipp'a Matthieux i Jacques'a Vergely'ego, powstał na wiadukcie, na dawnym trakcie kolejowym Paryż-Strasburg. Jest to park linearny, promenada biegnąca od placu Bastylii w kierunku Lasku Vincennes. Wędrówka promenada prowadzi poprzez parki Jardin Hector-Mallot, Jardin de Reuilly i Jardin de la Gare de Reuilly. Odrestaurowane arkady wiaduktu kolejowego, na których umieszczono 
park i ścieżki wykorzystujące wykop po tej samej, zamkniętej w 1969 r. linii kolejowej, to atrakcje parku o długości 4,5 km na obszarze 3,7 ha. Założenie o łącznej powierzchni 7 ha uzupełniają cztery dodatkowe parki (fot. 1 i 2 ).

\section{Park Atlantycki}

Park ten powstał w wyniku przebudowy Dworca Montparnasse w 1994 r. Zlokalizowany jest w południowej części miasta. Na planie Paryża (ryc. 1) oznaczono go cyfrą 1. Nazwę zawdzięcza temu, że z tego dworca odjeżdżają pociągi ekspresowe TGV w kierunku wybrzeża Atlantyku. Autorami śmiałego projektu przebudowy byli architekci François Brun i Michel Pena. Park o powierzchni 3,42 ha powstał na płycie wzniesionej $18,0 \mathrm{~m}$ ponad torami kolejowymi. Odwiedzający park, wypoczywający wśród wspaniałej, różnorodnej zieleni, w otoczeniu wielu obiektów małej architektury o symbolice marynistycznej, zupełnie nie odczuwają

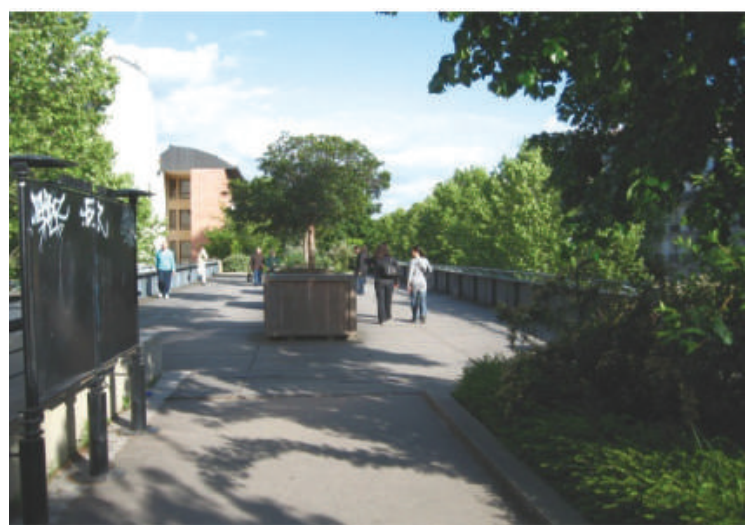

Fot. 2. Park Promenade Planteé w Paryżu Źródło: archiwum autorów

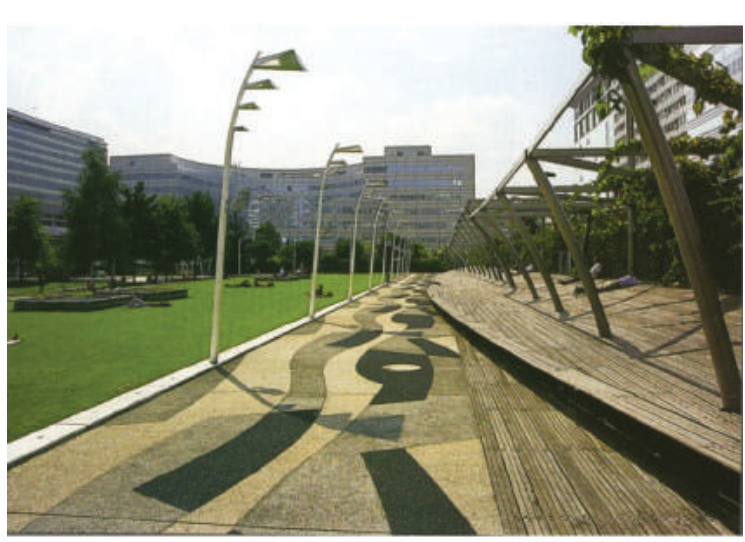

Fot. 3. Park Atlantycki w Paryżu Źródło: archiwum autorów tego, że kilkanaście metrów niżej znajdują się perony dworcowe. O kierunku odjeżdżających stąd pociągów - ku wybrzeżu oceanu, przypominają elementy wyposażenia parku, kojarzące się ze statkami i morzem. Są to stalowe maszty latarni, pergoli i ogrodzeń, drewniane pomosty i tarasy słoneczne z desek, przypominające pokłady statków zapraszające do wypoczynku, symboliczne łodzie i klify. Jest także „falujący” trawnik o powierzchni 0,6 ha. Całość dopełniają różne gatunki roślinności wydmowej, traw i trzcin, które poruszane wiatrem, wydają się powierzchnią wzburzonego oceanu. Powstała oaza zieleni w centrum wielkiego miasta, przestrzeń publiczna o funkcji rekreacyjnej, bardzo chętnie odwiedzana przez mieszkańców Paryża i przez turystów. Nowa funkcja nie zastąpiła ani nie wykluczyła funkcji starej. Dworzec nadal funkcjonuje, ukryty poniżej parku, a w przestrzeni między poziomem peronów i powierzchnią parku wygospodarowano kilka kondygnacji parkingów. Jest to znakomity przykład warstwowego wykorzystania cennych terenów śródmiejskich, gdzie nie 


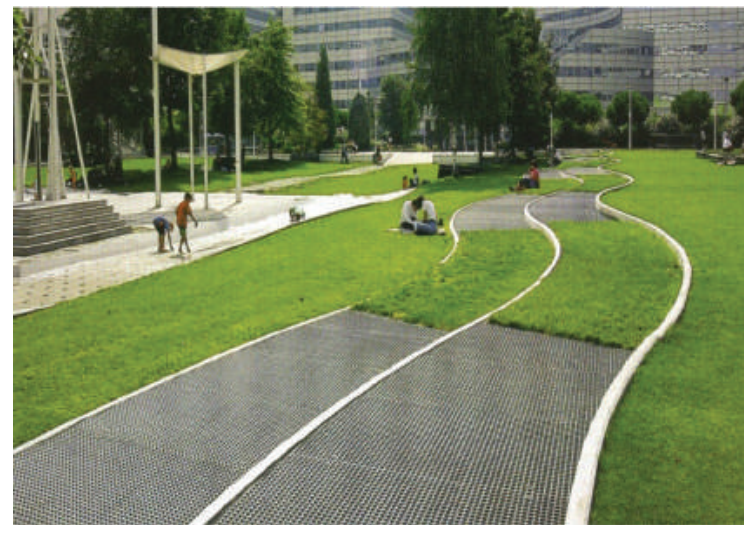

Fot. 4. Park Atlantycki w Paryżu Źródło: archiwum autorów

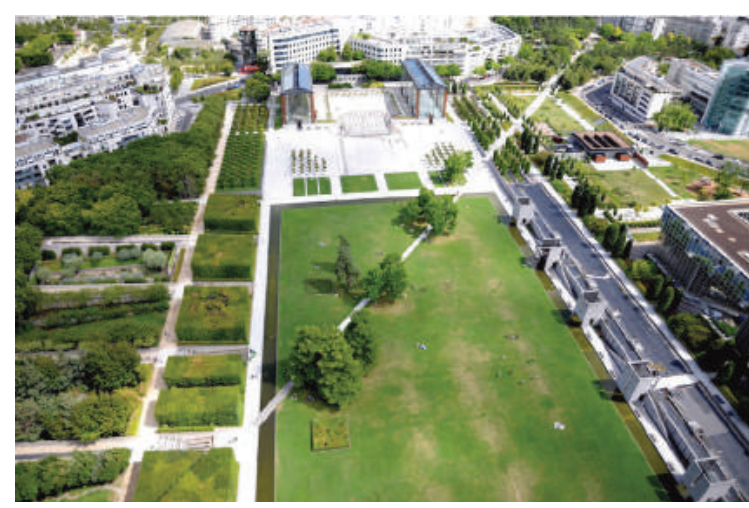

Fot. 5. Park André Citroën w Paryżu Źródło: archiwum autorów

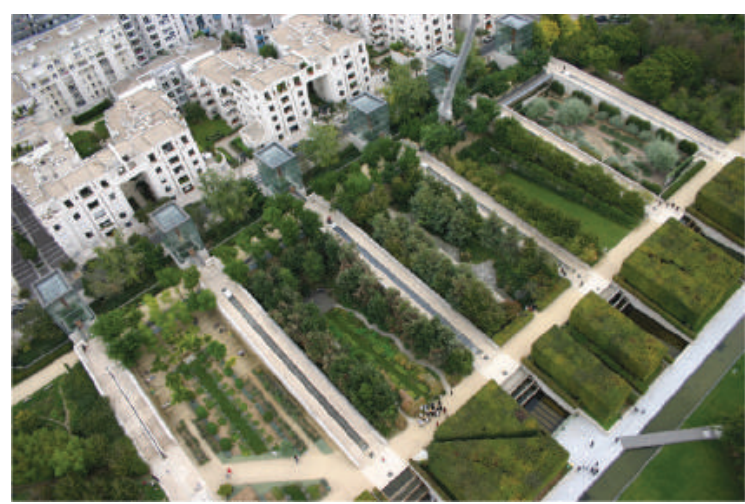

Fot. 6. Park André Citroën w Paryżu Źródło: archiwum autorów rezygnując z dotychczasowej funkcji dworcowej, a raczej ją wzbogacając, pozyskano nową ogólnodostępną przestrzeń na cele rekreacyjne (fot.3i4).

\section{Park André Citroën}

Park ten leży w południowozachodniej części miasta, w XV dzielnicy nieopodal południowowschodniego brzegu Sekwany. Na planie Paryża (ryc. 1) oznaczono go cyfrą 5. Jest to rozległe założenie na dawnych terenach przemysłowych fabryki Citroëna. Odznacza się regularną symetryczną kompozycją przestrzenną. Docelowo park ma osiągnąć powierzchnię 15 ha. Widok centralnej części parku przedstawia fotografia 5. Po lewej widoczne są różnie zaaranżowanie "gabinety" z uprawami ekologicznymi (fot. 6). Uprawy są zasilane m.in. ze źródeł deszczowych. Odzyskiwana woda służy też do czyszczenia terenu parku. Znajdują się tutaj liczne akweny w postaci płaszczyzn, fontann i długiej rynny-kanału, różne gatunki drzew i krzewów, rozległy trawnik, place zabaw dla dzieci, miejsca dla nastolatków a nawet solarium. Park powstał w wyniku konkursu zorganizowanego $\mathrm{w}$ połowie lat 80. XX w., z inicjatywy ówczesnego prezydenta Francji - François Mitterranda. Konkurs wygrały dwa zespoły, które stworzyły spójny projekt. Byli to projektanci ogrodów i krajobrazu: Gilles Clément i Allain Provost oraz architekci: Patrick Berger, Jean-François Jodry i Jean 
Paul Viguier. Zaprojektowali oni park w modnym w pierwszej połowie lat 90 . XX w. stylu postmodernistycznym. Układ przestrzenny parku nawiązuje do założeń barokowych, ale ład i spokój uporządkowanej geometrycznie przestrzeni zakłóca ścieżka biegnąca przez całość założenia po ukosie. Oficjalne otwarcie parku nastąpiło w 1992 r.

\section{Park Bercy}

Park ten znajduje się w południowo-wschodniej części miasta, w XII dzielnicy w sąsiedztwie znanej hali sportowej, w pobliżu Sekwany, na jej brzegu północnowschodnim. Na planie Paryża (ryc. 1) oznaczono go cyfrą 6. Było to niegdyś przedmieście przemysłowoskładowe. Zachowano budynki dawnych składów win wykorzystując je na sklepy, restauracje, kawiarnie, galerie sztuki i biura. Uliczka biegnąca między dwoma szeregami tych budynków - dawna bocznica kolejowa stała się atrakcyjnym ciaggiem spacerowym. Wyposażono ją bogato w zieleń, wiklinowe ławki - kosze połączone łukowatymi pergolami. (fot. 7). W parku wyeksponowano fragmenty dawnych nawierzchni ulic: bruk i urządzenia infrastruktury technicznej - żeliwne klapy włazów i szyny tramwajowe. Stworzono kopiec - górkę widokowa. Powierzchnia parku wynosi 13 ha. Wykonany został zgodnie z koncepcją francuskiego projektanta Iana Le Caisne'a. Zachowano poprzeczne alejki składów odchodzących od Sekwany oraz istniejący starodrzew ponad 500 platanów. Kompozycja przestrzenna została zbudowana na kanwie prostokątnych podziałów (fot. 8.),

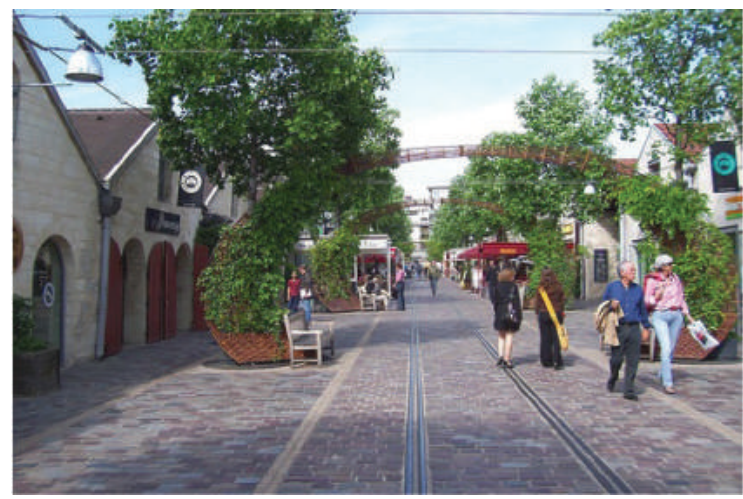

Fot. 7. Park Bercy w Paryżu

Źródło: archiwum autorów

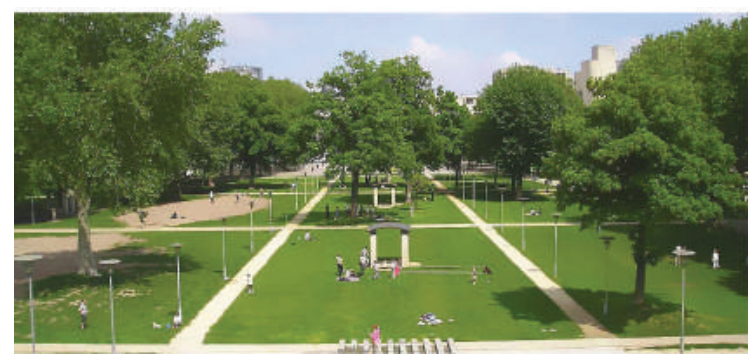

Fot. 8. Park Bercy w Paryżu

Źródło: archiwum autorów

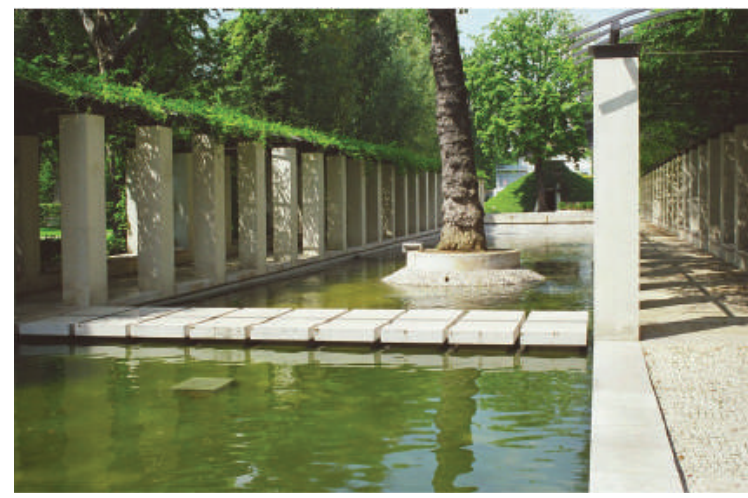

Fot. 9. Park Bercy w Paryżu Źródło: archiwum autorów 


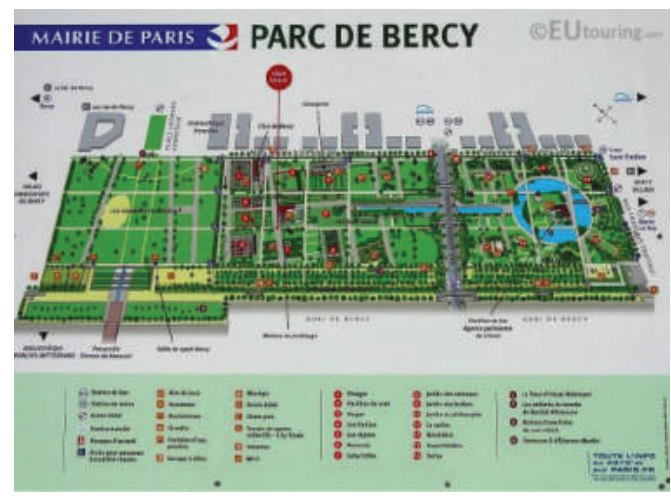

Fot. 10. Park Bercy w Paryżu

Źródło: archiwum autorów

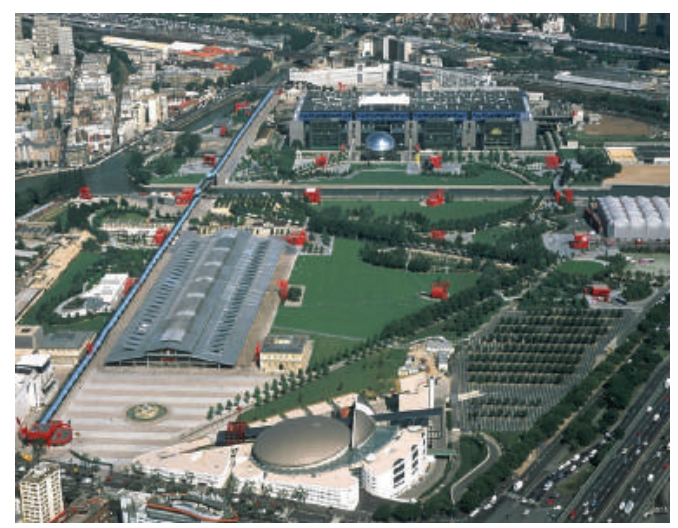

Fot. 11. Park Villette w Paryżu Źródło: internet

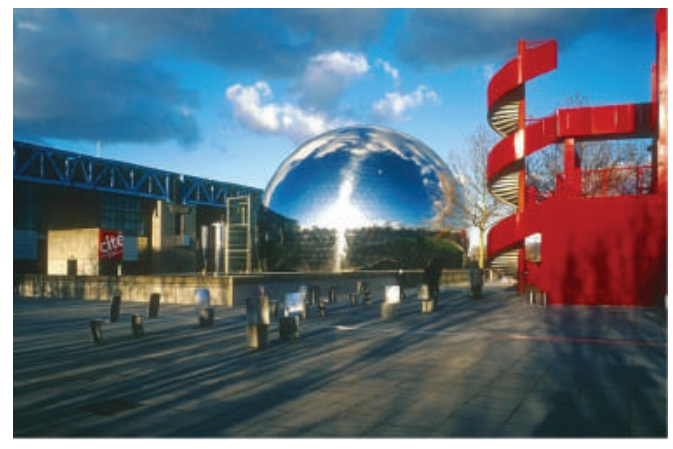

Fot. 12. Park Villette w Paryżu Źródło: internet zachowując ciągłość historyczną miejsca. Ważnym elementem parku są akweny (fot. 9). Park składa się z trzech ogrodów: Romantycznego ze stawami i wydmami, Kwietnego - złożonego z dziewięciu tematycznych ogrodów, inspirowanych przez francuskie ogrody oraz Ogrodu Łąki - otwartych trawników w cieniu wysokich drzew (fot. 10). Park połączony jest pieszą kładką nad Sekwaną z obszarem, gdzie znajduje się Biblioteka im. Mitteranda.

\section{Park La Villette}

Park zlokalizowany jest przy Bulwarze Periferic, w północno-wschodniej części miasta, w XIX dzielnicy. Na planie Paryża (ryc. 1) oznaczono go cyfrą 7 (fot. 11). Powierzchnia parku wynosi 55 ha. W 1982 r. władze Paryża ogłosiły międzynarodowy konkurs na Park XXI wieku. Wpłynęło 450 prac. Laureatem konkursu został Bernard Tschumi, który w swoim projekcie, zgodnym z duchem postmodernizmu, stworzył przestrzeń wielowątkową. Park wzbogacają funkcje edukacyjne i kulturalne. Park ten zlokalizowano na terenie byłej paryskiej rzeźni i targu zwierząt. Zachowany został zabytkowy budynek dziewiętnastowiecznej hali - rzeźni. W miejscu, gdzie zwierzęta prowadzone na rzeź piły wodę zlokalizowano okrągła, barokową $\mathrm{w}$ formie fontannę $\mathrm{z}$ rzeźbami lwów. Park jest podzielony przez dwa kanały - St. Denis Canal niegdyś używany do transportu ładunków i towarów, oraz Ourcq Canal, dawniej dostarczający wodę pitną dla miasta Paryża. Całość jest podzielona na 10 ogrodów tematycznych, w tym ogród lustra, wydm, cieni, bambusa, 
mgły, winorośli. Charakterystycznym elementem jest obejmująca cały obszar parku siatka folies, czyli czerwonych obiektów - kiosków o różnych funkcjach, tworząca regularne kwadraty (fot. 11 i 12). $\mathrm{Na}$ terenie parku zlokalizowano nowe obiekty kubaturowe: halę widowiskową Zenith na 6 tys. miejsc, Muzeum Nauki i Techniki, otoczone sztucznym akwenem (fot. 13), kino sferyczne "La Geode” w postaci lustrzanej kuli o średnicy $36 \mathrm{~m}$, która wydaje się unosić nad lustrem wody (fot. 12). W drugim etapie, po 1995 r., wzniesiono dwa obiekty: Konserwatorium i "Świat Muzyki", zawierające sale koncertowe autorstwa Christiana de Portzamparc. Najnowszym obiektem z 2015 r. jest zlokalizowany w pobliżu hali Zenith budynek filharmonii autorstwa słynnego francuskiego architekta Jeana Nouvela (fot. 14). Architekt nie przybył na uroczystość otwarcia filharmonii, w proteście przeciwko zmniejszeniu środków finansowych, niezbędnych do zakończenia projektu zgodnie $\mathrm{z}$ wizją artysty.

\section{Park Belleville}

Park zrealizowany został poza śródmieściem Paryża w XX dzielnicy, poza Bulwarem Periferic - obwodnicą Paryża. Nie mieści się na schemacie planu miasta Paryża (ryc. 1). Kierunek oznaczono cyfrą 4. Jest to obszar, gdzie już w latach 70 . XX w. wyburzono całe kwartały kamienic, typowych dla miasta i przedmieść przemysłowych, nieprzyjaznych dla człowieka, pozbawionych światła i zieleni. $\mathrm{W}$ ich miejscu powstała nowa zabudowa.

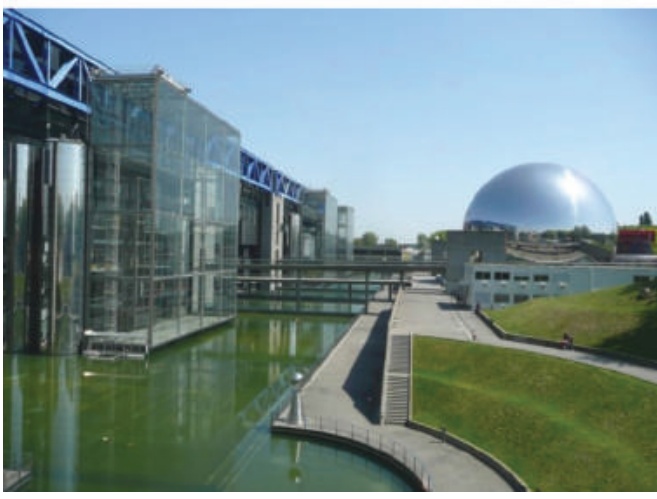

Fot. 13. Park Villette w Paryżu Źródło: archiwum autorów

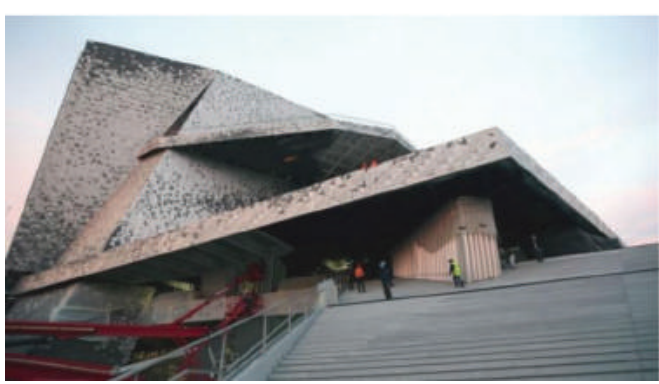

Fot. 14. Filharmonia, Park Villette w Paryżu Źródło: internet

Park stworzono w miejscu dawnej kopalni

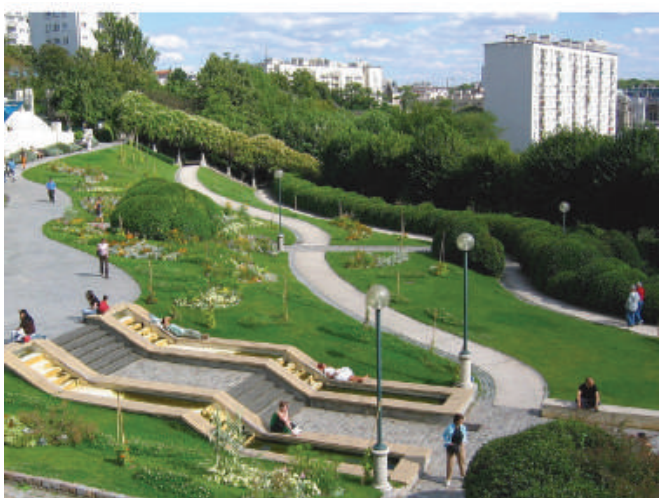

Fot. 15. Park Belleville w Paryżu Źródło: internet 
gipsu. Jego powierzchnia to 4,5 ha. Autorem projektu tego „Pięknego Miasta”: jest architekt François Debulois. Wykorzystując dawne wyrobisko uformował tarasy i skarpy oraz ciąg kaskad i basenów. Założenie jest symetryczne, a jego główna oś ma długość 100 m. Układ tarasów podkreślony został zwartymi nasadzeniami krzewów (fot. 15). Na szczycie wzgórza znajduje się „Belweder” z oranżerią. Jest to wspaniały punkt widokowy, z którego można podziwiać niemal cały Paryż (fot. 16).

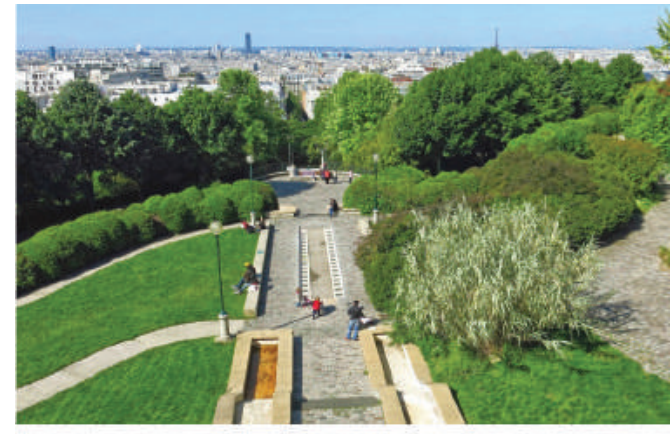

Fot. 16. Park Belleville w Paryżu Źródło: internet

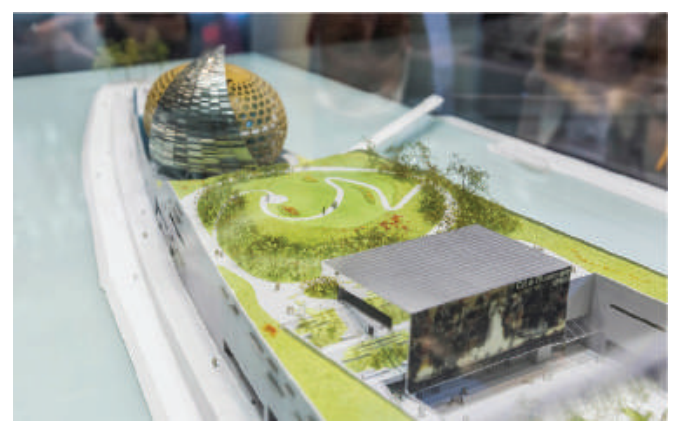

Fot. 17. Centrum Muzyki na wyspie Seguin z parkiem na dachu

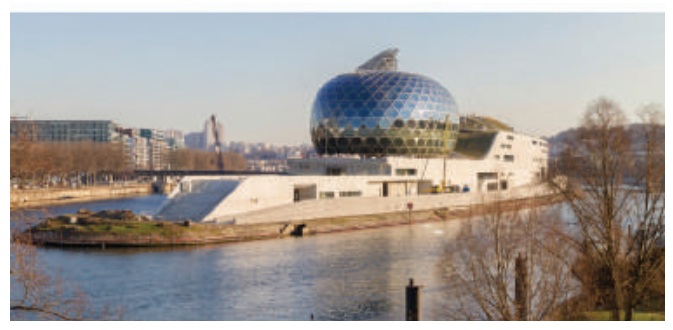

Fot. 18. Centrum Muzyki na wyspie Seguin z parkiem na dachu Źródło: internet Źródło: internet

\section{Park na wyspie „Île Seguin”}

Wiosną 2017 r. zakończono budowę Centrum Muzyki na wyspie Segiun w Boulogne-Billancourt pod Paryżem, na południowy zachód od śródmieścia. Był to zdewastowany teren poprzemysłowy, który został przekazany miastu w 2010 r., po przeniesieniu produkcji ze starej fabryki Renault. Wyspa o powierzchni 11,5 ha stała się sercem dużego projektu rewitalizacji całej przemysłowej dzielnicy Seguin o powierzchni 74 ha, leżącej wzdłuż nabrzeża Sekwany. Głównym projektantem jest francuski architekt Jean Nouvel. Do projektowania ogrodu na wyspie Seguin włączyli się: znany architekt krajobrazu Michael Desvigne, artysta-kreator światła Yanna Kersalé oraz grafik Ruedi Baura - projektant systemu informacji wizualnej. Centrum Muzyki, budynek w kształcie statku projektu architekta Shigeru Ban, zajmuje północną część wyspy w kształcie wydłużonej fasolki. Na dachu budynku, w którym znajdują się trzy sale koncertowe (dolna na 6 tys., środkowa na 2 tys. i górna 1200 miejsc) zrealizowano park. Obiekt nazwano „Bańką” ze względu na charakterystyczny kształt górnej sali koncertowej (fot. 17 i 18). Południowa część wyspy 
w całości zostanie zagospodarowana jako park. Docelowo obszar ma stać się miejscem wyjątkowych, kulturalnych, artystycznych, innowacyjnych i zrównoważonych pomysłów na przestrzeń publiczną. Produkty z rozbiórki starej fabryki Renault poddano recyklingowi i wykorzystano do zagospodarowania wyspy. Całkowite zakończenie prac przewidziano dopiero na $2023 \mathrm{r}$.

\section{Podsumowanie}

Tereny opuszczone, odzyskane dla miasta, mają wielki potencjał rozwojowy. Nadają się zwłaszcza do wykorzystania na funkcje rekreacyjne i kulturalne. Najlepiej świadczą o tym opisane powyżej realizacje. Podobne założenia parkowe, wzbogacone o obiekty sportowe, widowiskowe i kulturalne powstały i nadal powstają w wielu miastach świata. Następuje dzięki temu ponowne włączenie zdegradowanych obszarów kryzysowych w życie miasta.

\footnotetext{
Krzysztof Muszyński - architekt i urbanista, nauczyciel akademicki, emerytowany profesor Instytutu Architektury i Urbanistyki Politechniki Łódzkiej oraz Wyższej Szkoły Ekologii i Zarządzania w Warszawie. Autor i współautor wielu projektów architektonicznych i urbanistycznych. Autor wielu nagrodzonych i wyróżnionych konkursów architektoniczno-urbanistycznych.

Krzysztof Muszyński, architect and urban planner, academic teacher, retired professor of the Institute of Architecture and Urban Planning at the Lodz University of Technology and the University of Ecology and Management in Warsaw. Author and co-author of many architectural and urban projects. Author of many architectural and urban competitions awards.
}

Elżbieta Muszyńska - architektka i urbanistka, nauczycielka akademicka w Instytucie Architektury i Urbanistyki Politechniki Łódzkiej oraz w Wyższej Szkole Ekologii i Zarządzania w Warszawie. Autorka i współautorka wielu projektów architektonicznych i urbanistycznych. Współautorka wielu nagrodzonych i wyróżnionych konkursów architektoniczno-urbanistycznych.

Elżbieta Muszyńska, architect and town-planner, academic teacher at the Institute of Architecture and Urban Planning at the Lodz University of Technology and at the University of Ecology and Management in Warsaw. Author and co-author of many architectural and urban projects. Co-author of many architectural and urban competitions awards. 